УДК 304:007

https://doi.org/10.34142/24130060.2020.21.2.07

\title{
ПОЛІТИЧНІ ЛІДЕРИ ПРО ПАНДЕМІЮ СОVID-19: СОЦІАЛЬНО-ФІЛОСОФСЬКІЙ ВИМІР
}

\author{
О. В. Скалацька \\ Національний університет «Одеська Юридична Академія»
}

В статті розглянуто соціально-філософський вимір звернень політиків на початку пандемії Covid-19. Зазначається, щуо новим каналом політичної комунікачії є соціальні мережі, які містить низку переваг встановлення зворотного зв'язку з електоратом. Акиентується увагу на тому, щзо пандемія Covid-19 стала викликом для сучасного суспільства, проблемою, яка трансформувала традиційні соиіальні практики та встановлені норми суспільного життя. Встановлено, щзо політики, як і інші лідери думок роз'яснювали необхідність впровадження нокдауну та соціальної ізоляиії, соиіальної дистанції для запобігання збільшення кількості захворювань новим вірусом.

Ключові слова: електорат, локдаун, пандемія Covid-19, сочіальні мережі, цінності.

\section{ПОЛИТИЧЕСКИЕ ЛИДЕРЫ О ПАНДЕМИИ COVID-19: СОЦИАЛЬНО-ФИЛОСОФСКОЕ ИЗМЕРЕНИЕ}

\section{Е. В. Скалацкая}

В статье рассмотрено социально-философское измерение обращений политиков 8 начале пандемии Covid-19. Отмечается, что новым каналом политической коммуникации являются сочиальные сети, которые содержат ряд преимуществ установления обратной связи с электоратом. Акцентируется внимание на том, что пандемия Covid-19 стала вызовом для современного общества, проблемой, которая трансформировала традищионные социиальные практики и установленные нормы общчественной жизни. Установлено, что политики, как и другие лидеры мнений, разъясняли необходимость введения локдауна и сочииальной изолящии, соџиальной дистанции для предотвращения увеличения количества заболеваний новым вирусом.

Ключевые слова: локдаун, пандемия Covid-19, социальные сети, иенности, электорат.

\section{POLITICAL LEADERS ABOUT THE COVID-19 PANDEMIC: SOCIAL-PHILOSOPHY SENSES}

\section{O. Skalatska}

The article considers the social-philosophy concept of politicians' appeals at the beginning of the Covid-19 pandemic. It is noted that the new channel of political communication is social networks, which have a number of advantages of establishing feedback from the electorate. Communication technologies used in public relations are analyzed. Emphasis is placed on the fact that the Covid-19 pandemic has become a challenge for modern society, a problem that has transformed graceful social practices and established norms of public life. It is

(C) О. В. Скалацька, 2020 
argued that politicians, like other opinion leaders, have explained the need for a knockdown and social isolation, a social distance to prevent an increase in the incidence of the new virus. It is noted that in their appeals, the political letters of the states emphasized the protection of citizens and the unity of the nation, arguing that the unification of citizens will help solve a difficult problem. Emphasis is placed on the fact that political leaders have defined the pandemic as a "difficult time" in the history of the nation's development, and human life is becoming the main value for which physicians and politicians are fighting. It is noted that the task of social philosophy is to integrate interdisciplinary knowledge and empirical research to create a protective model of careful adaptation of individuals to new living conditions. It is emphasized that the philosophical foundations of these changes are connected with the reversal of traditional, in some cases stable, ideas about the structure of society, social practices, and the activities of actors. It is established that the new movement of society takes place simultaneously in real and virtual spaces. In this case, the messages of politicians on social networks helped to consolidate the nation, explain the need to comply with restrictions, prevent the spread of panic in the population, emphasize the value of human life. The analysis of this issue can be continued in the framework of the study of manipulative technologies, conducting PR-campaigns, influencing public opinion and the behavior of the electorate.

Key words: lockdown, Covid-19 pandemic, social networks, values, electorate.

Постановка проблеми. Пандемія Covid-19 стала викликом, який загострив існуючі соціальні проблеми у сферах суспільного життя. Суттєво змінились умови соціальній взаємодії, які підпорядковувались новим принципам, спрямованим на захист населення від зараження та зменшення кількості захворювань вірусом. Морально-етична та юридична природа цінності людського життя також потребувала дотримання соціальної дистанції, соціальної ізоляції, локдауну. Соціальна активність індивідів 3 реального простору перемістилась у віртуальний, який на період карантину став основним джерелом інформування. Саме повідомлення інтернет-видань та у соціальних мережах впливали на рішення індивідів, їх емоційних стан. Дослідження медійних повідомлень політичних діячів на початку пандеміі Covid-19 дозволить простежити зміни у просторі суспільних відносин, використанні цієї значної події як інфоприводу та піар-технології, впливу соціальних мереж на соціальні практики індивіда.

Аналіз актуальних досліджень. В низці робіт з філософії, соціології, політології, соціальних комунікацій обгрунтовуються переваги застосування соціальних мереж в політичній комунікації. Це дослідження таких авторів як
Ю. Данько, Л. Іващук,
А. Клячин,
А. Краснякова,
О. Рупинський та ін.

Соціальні мережі як простір комунікації з електоратом проаналізовано в 
роботах західних вчених на прикладах $\mathrm{PR}$-технологій в передвиборчих президентських кампаніях (Leuschner, 2012). Також було проаналізовано аккаунти політичних діячів в соціальній мережі Instagram.

В західній та українській науці поступово з'являються дослідження, присвячені змінам, які відбулись у світі після появи Covid-19. Особливо важливим $\epsilon$ аналіз перших відгуків суспільства та окремих лідерів на поширення нового вірусу. Актуальним є розгляд соціально-філософських сенсів, які використовувались в промовах політичних лідерів для запобігання виникнення паніки серед населення та підтримки впровадження локдауну на території всієї країни.

Метою статті $\epsilon$ аналіз звернень та заяв політичних лідерів різних країн світу на початку пандемії Covid-19 у контексті соціально-філософського виміру. Для досягнення поставленої мети необхідно виконати наступні завдання:

- дослідити особливості політичної комунікації в соціальних мережах;

- визначити актуальні соціально-філософські питання на початку пандемії Covid-19;

- проаналізувати повідомлення політичних діячів в офіційних аккаунтах в соціальній мережі Instagram.

Виклад основного матеріалу. У XX столітті комунікація політичних лідерів та партій здійснювалась за допомогою традиційних медіа (друковані видання, телебачення, радіо), які в сучасному суспільстві суттєво поступаються впливу на аудиторію нових медіа. Особливо ефективними $є$ комунікація в соціальних мережах, які використовуються для просування іміджу політика та партії, встановлення зворотного зв'язку з електоратом.

Український дослідник Ю. Данько виокремлює у розвитку політичної комунікації в інтернеті два етапи: інформаційний, коли інформація про діяльність політиків поширюється в мережі; медіатизація політики політичні лідери та партії використовують комунікаційні можливості інтернету як піар-технологію. Автор зазначає, що комунікація традиційних 
ЗМІ є односторонньою, та дозволяє деяким «структурам впливати на адресата і підтримувати контроль над підвладними суб’єктами» (Danko, 2015, s. 205).

Взаємодія соціальних суб’єктів в просторі інтернету, навпаки є багатосторонню та має наступні переваги: безпосередня опосередкована взаємодія 3 політиками в соціальних мережах, блогах, чатах тощо; відсутність прив'язки до фізичного часу та місця (часова та просторова дифузність), які моделюються користувачами у віртуальному просторі; тенденція до конвергенції та «толерантне ставлення до політичної невизначеності іншого суб’єкта взаємодії, пошуку компромісів щодо прийняття його точки зору» (Krasniakova, 2015, s. 245); активність та власні погляди комунікантів нівелюють вагомість соціальної і вікової диференціації користувачів. Також необхідно додати, що соціальні мережі дозволяють політикам подолати фізичні кордони, комунікувати 3 індивідами без особистої зустрічі, впливати на формування громадської думки.

Західні дослідники зазначають, що починаючи з 1992 року в Америці президентські кампанії поступово збільшують використання нових медіа у веденні піар-кампаній (Leuschner, 2012, р. 5). Так, президентська кампанія Б. Клінтона у 1992 році в віртуальному просторі використовувала тільки сайт, на якому була розміщена інформація про кандидата. Аудиторія інтернету була незначною, саме тому усі політтехнології орієнтувались на традиційні 3МI, масову розсилку, телефонні розмови. На думку західних вчених першою успішною політичною передвиборчою кампанією в інтернеті була стратегія Говарда Діна у 2004 р. Політтехнологи використовували не лише мережу сайтів, вони розробили блог, який виконував функції головного джерела інформації про кандидата.

Саме в той час формуються нові технології аудиторії до взаємодії, які технічно вдосконалюються у соціальних мережах залежно від їх формату: гіперпосилання, використання візуалізації контенту та мультимедіа, 
реєстрація електронної пошти, опитування, інтернет-дискусії на форумах, коментарі та ін.

32008 року соціальні мережі стали платформою для політичних комунікацій. В президентських виборах 2008 року кандидати для взаємодії 3 електоратом користувались Facebook, Twitter, YouTube. Це значно змінило проведення піар-кампаній, які здійснювались в реальному та віртуальному просторах.

Поширення більшості звернень американських політиків відбувається в соціальній мережі Twitter. Політики та користувачі використовують хештеги, які дозволяють зазначити певне місце, ім’я особистості, дію, проблему, що спрощує іiі пошук в мережі. Технології соціальних мереж створюють ефективний зворотний зв’язок між політиками та електоратом. Так формується суспільний дискурс, що сприяє розвитку демократії, розв’язанню актуальних питань життедіяльності соціуму.

Особливістю соціальної мережі Instagram є візуальний контент, фахівці з соціальних комунікацій сперечаються стосовно впливовості текстового повідомлення та фотографії: одні обгрунтовують первинність іконічних сенсів, якісність зображення та обгрунтують думку, що повідомлення аудиторія практично не читає; інші, навпаки, стверджують, що якісний візуальний контент повинен доповнюватися відповідним текстом, який також впливає на аудиторію.

Пандемія Covid-19 підкреслила не тільки медичні, політичні кризи сучасного суспільства, вона наочно продемонструвала руйнування деяких сфер суспільного життя та повернула людство до вирішення соціальних питань у межах системи цінностей людського життя, прав і свобод. Соціальні практики повсякденного життя індивіда обмежились вимогами карантину, серед яких ключовими були соціальна дистанція, самоізоляція, заборона проведення масових заходів, носіння у публічних місцях захисних масок та рукавичок. У всьому світі бібліотеки, архіви, музеї дозволили безкоштовний доступ до своїх інтернет-ресурсів; театри та музичні виконавці почали давати 
онлайн-вистави; фахівці різних напрямків проводили безкоштовні майстеркласи в режимі онлайн. Так, різноманіття онлайн занять створило умови нового простору, який існував поряд з вражаючими статистичними даними про поширення та перебіг захворювання Covid-19. Життя в реальному просторі змінилось пустими вулицями та постійними обмеженнями, закритими кордонами, уповільнились темпи розвитку, виробництва, споживання.

У 2020 році голови держав повинні були своєчасно реагувати на стрімкий розвиток захворінь населення країни на Covid-19, вони були повинні запровадити певні заходи для стримування розвитку вірусу та захистити населення країни. На початку пандемії для запобігання поширення панічних настроїв серед населення країни політики поряд 3 медичними працівниками, епідеміологами та вірусологами роз'яснювати необхідність обмежень та дотримання соціальної ізоляції.

Політтехнологи могли використати ситуацію з пандемією Covid-19 для збільшення медіа активності політичних лідерів та налагодження комунікації 3 електоратом. Ця подія стала не просто викликом або інформаційним приводом, вона кардинально вплинула на соціальні практики індивідів, які для захисту населення змінили соціальні практики, що було регламентовано на державному рівні. Нові соціальні стандарти повсякденного життя грунтувались навколо низки головних вимог, спрямованих на забезпечення соціальної дистанції та ізоляції. Китай став першою країною у світі, яка почала обмежувати пересування між містами, в яких простежувалась різка динаміка рості кількості захворювань новим вірусом. Впровадження локдауну та домашнього карантину змінило соціальні практики індивідів, які були можливі лише у віртуальному просторі (робота навчання стали дистанційними). Таким чином утворився новий простір, який могли використовувати політичні сили для впливу на електорат та просування своїх ідей. 
В поширенні заяв політиків у соціальних мережах використовується низка переваг комунікаційного середовища інтернету (доступність розміщеної інформації, взаємодія та зміна ролей комуніканта і комуніката; встановлення зворотного зв'язку за допомогою інтерактивності; використовування гіперпосилань та хештегів для пошуку інформації), що дозволяє взаємодіяти з електоратом та впливати на громадську думку.

В Україні найбільшого застосування отримали соціальні мережі Instagram та Facebook. Формат мережі Twitter $є$ досить популярним в багатьох країнах світу, в Україні вона майже не використовується. Також для поширення іміджу використовують канали на відеохостингу YouTube.

В Україні соціальні мережі Facebook та Instagram постійно конкурують між собою за кількістю користувачів та завантажень мобільних версій. Згідно 3 даними останніх досліджень 31\% населення користується Facebook, 26\% Instagram (Radzikhovska, 2019). У соціальній мережі Instagram домінують світлини та інші види візуального контенту (графічні зображення, відеоролики, анімація), текстові повідомлення можуть біти відсутні. Контент мережі Facebook може поєднувати візуальну i текстову форми, або використовувати кожну окремо. На відміну від Instagram, користувач має можливість створювати великі за об’ємом тексти. Користувачі обох мереж мають можливість писати коментарі, отримувати відповіді, писати приватні повідомлення. Це відтворює двосторонню комунікацію (двосторонній процес обміну повідомленнями між комунікаторами) між власником акаунту та аудиторією мережі або між підписниками акаунту та розширення аудиторії. Для полегшення пошуку необхідної інформації використовуються та розробляються нові хештеги.

Президенти західних країн, одразу почали використовували комунікаційні можливості соціальної мережі Instagram для ведення інформаційної політики стосовно загрози, пов'язаною зі стрімким поширенням Covid-19. Основні сенси їх повідомлень були спрямовані не стільки на візуалізацію, скільки роз'яснення необхідності дотримання правил 
соціальної дистанції та інформування населення про засоби захисту від вipycy.

Тематика Covid-19 в аккаунтах політиків в соціальних мережах 3’явилась наприкінці лютого, початку березня, напередодні прийняття рішення впровадження локдауну, закриття кордонів, мінімізації активності громадян у соціальному просторі міста. Так, в аккаунті Президента Сполучених Штатів Америки Дональда Трампа були розміщені візуальні повідомлення, які доповнювались роз'ясненням в тексті, спрямовані на надання рекомендацій 3 захисту від Covid-19 (симптоми захворювання; звернення до мандрівників, літніх людей, тих, у кого $є$ проблеми зі здоров’ям, відкласти всі подорожі; підписання Прокламації про оголошення надзвичайної ситуації в країні у зв’язку зі спалахом нового вірусу (President Donald J. Trump, 2020).

Президенти європейських країн, в яких одразу була зафіксовано стрімке поширення та велика кількість смертей від Covid-19, також поширювали в соціальних мережах свої офіційні заяви про надзвичайну ситуацію в країні. Президент Італії Серджо Матарелла звертався до нації та констатував, що країна переживає «сумні сторінки історії», за які високу ціну заплатили старші покоління (Presidency of the Italian Republic Official Account, 2020). У цих зверненнях розкривається сенс ідеї інтеграції нації перед актуальними проблеми, що дозволяє їх подолати.

В аккаунті президента Франції Емманюеля Макрона (Président de la République française, 2020) неодноразово з’являлись пости подяки громадянам, які допомагають медикам. У своїй заяві про початок локдауна Е. Макрон пояснив, що ці заходи, необхідні для безпеки всіх, подолати кризу неможливо без індивідуальної і колективної дисципліни. Президент Франції так само говорить про важкі часи, які потрібно пережити разом, об’єднатись та захистити себе.

В офіційному аккаунті президента України Володимира Зеленського (Володимир Зеленський, 2020) в Instagram поширювались його відео 
звернення до громадян країни, в яких роз'яснювались рішення для запобігання поширення Covid-19. Одним з перших з’явилось відео, в якому зазначалась необхідність єднання нації перед новим вірусом, та важливість поверненням громадян 3 інших країн на батьківщину. Також в промовах голови держави лунали повідомлення, спрямовані на запобігання виникнення панічних настроїв, повідомлялось, що держава спирається на досвід інших країн в боротьбі з вірусом та використовує навіть «непопулярні та жорсткі рішення» для порятунку життя.

Необхідно зазначити, що в аккаунтах політичних діячів в соціальній мережі Instagram наявна тематика пандемії Covid-19, яка репрезентується в наступних відео та текстових повідомленнях: пости, присвячені поширенню вірусу та загрозам; вимога носіння маски репрезентується у відповідних фотографіях; відео, на яких зображено проведення домашнього карантину; розвінчування дезінформації; повідомлення про важливі державні постанови та рішення. Ці повідомлення створювали комунікацію політиків 3 електоратом, єднали їх у вирішенні актуальної проблеми.

Висновки і перспективи подальших досліджень. Феномен пандемії Covid-19, ïi вплив на соціальні трансформації та світоглядні орієнтири, потребує окремого дослідження. Завданням соціальної філософії $\epsilon$ інтегрування міждисциплінарних знань та емпіричних досліджень для створення захисної моделі ретельної адаптації індивідів до нових умов існування. Необхідно підкреслити, що філософські підвалини цих змін пов’язані саме з перевертанням традиційних, у деяких випадках сталих, уявлень про структуру соціуму, соціальні практики, діяльність акторів. Новий рух суспільства відбувається одночасно у реальному та віртуальному просторах. У даному випадку, повідомлення політичних діячів у соціальних мережах сприяли консолідації нації, роз’ясненню необхідності дотримання обмежень, запобіганню поширенню панічних настроїв населення, наголошенні на цінності людського життя. Аналіз цієї проблематики може бути продовжено в межах дослідження маніпулятивних технологій, 


\section{проведення PR-кампаній, впливу на громадську думку та поведінку \\ електорату.}

\section{ЛІТЕРАТУРА}

1. Володимир Зеленський. Президент України, 2020. [online] Доступно: https://www.instagram.com/zelenskiy_offici $\mathrm{al} / ? \mathrm{hl}=\mathrm{ru}$. [04 Листопад 2020].

2. Данько, Ю., 2015. Соціальні мережі як засіб політичної комунікації. Evropsky politicky a pravni diskurz, 2(2), c. 204-209.

3. Іващук, Л., 2011, Соціальні мережі Інтернету в сучасній політичній комунікації. Наукові праџі Наџіональної бібліотеки України ім. В. І. Вернадського, 32, c. 63-70.

4. Клячин, А. К., 2019, Політична комунікація в сучасному суспільстві: альтернативні повідомлення та чинники диверсифікації інформаційних потоків. Гілея: науковий вісник, 145(3), с. 56-59.

5. Краснякова, А. О., 2015. Інтернеткомунікація як чинник становлення політичної суб'єктності особистості. Проблеми політичної психологї̈, 2, с. 243253.

6. Radzikhovska, O., 2019. Яка соціальна мережа найпопулярніша в Україні дослідження [online]. Доступно: https://bit.ua/2019/09/social_media/2019/ [04 Листопад 2020].

7. Leuschner, K. E., 2012. The Use of the Internet and Social Media in U.S. Presidential Campaigns: 1992-2012. [online] Available at: https://www.academia.edu/1510408/The_Us e_of_the_Internet_and_Social_Media_in_U_ S_Presidential_Campaigns_1992_2012. [04 November 2020].

8. Presidency of the Italian Republic Official Account, 2020. [online] Available at: https://www.instagram.com/quirinale/. [04 November 2020].

9. Président de la République française, 2020. [online] Available at: https://www.instagram.com/emmanuelmacro n/?hl=ru. [04 November 2020].

10. President Donald J. Trump, 2020. [online] Available at: https://www.instagram.com/realdonaldtrump /?hl=uk [04 November 2020].

\section{REFERENCES}

1. Volodymyr Zelenskyi. Prezydent Ukrainy, 2020. Dostupno: https://www.instagram.com/zelenskiy_offici al/?hl=ru. [04 Lystopad 2020].

2. Danko, Yu., 2015. Sotsialni merezhi yak zasib politychnoi komunikatsii. Evropsky politicky a pravni diskurz, 2(2), s. 204-209.

3. Ivashchuk, L., 2011. Sotsialni merezhi Internetu $\mathrm{v}$ suchasnii politychnii komunikatsii. Naukovi pratsi Natsionalnoi biblioteky Ukrainy im. V. I. Vernadskoho, 32, s. $63-70$.

4. Kliachyn, A. K., 2019, Politychna komunikatsiia $\mathrm{V}$ suchasnomu suspilstvi: alternatyvni povidomlennia ta chynnyky dyversyfikatsii informatsiinykh potokiv. Hileia: naukovyi visnyk, 145(3), s. 56-59.

5. Krasniakova, A. O., 2015. Internetkomunikatsiia yak chynnyk stanovlennia politychnoi subiektnosti osobystosti. Problemy politychnoi psykholohii, 2, s. 243253.

6. Radzikhovska, O., 2019. Yaka sotsial'na merezha najpopuliarnisha $v$ Ukraini doslidzhennia. [online] Dostupno: https://bit.ua/2019/09/social_media/2019/ [04 Lystopad 2020].

7. Leuschner, K. E., 2012. The Use of the Internet and Social Media in U.S. Presidential Campaigns: 1992-2012. [online] Available at: https://www.academia.edu/1510408/The_Us e_of_the_Internet_and_Social_Media_in_U_ S_Presidential_Campaigns_1992_2012. [04 November 2020].

8. Presidency of the Italian Republic Official Account, 2020. [online] Available at: https://www.instagram.com/quirinale/. [04 November 2020].

9. Président de la République française, 2020. [online] Available at: https://www.instagram.com/emmanuelmacro n/?hl=ru. [04 November 2020].

10. President Donald J. Trump, 2020. [online] Available at:

https://www.instagram.com/realdonaldtrum p/?hl=uk [04 November 2020]. 


\section{Інформація про автора}

Скалацька Олена Віталіївна - доцент кафедри журналістики Національного університету «Одеська Юридична Академія», e-mail: elena-s2008@ukr.net; ORCID: https://orcid.org/0000-0003-1439-8753.

Стаття надійшла до редакції: 22.10.2020 р. $\quad$ Прийнята до друку: 10.11.2020 p. 